Portland State University

PDXScholar

6-16-2021

\title{
Reclaiming the "I": Memoir Writing as Feminist Activism
}

Michela Sottura

Portland State University

Follow this and additional works at: https://pdxscholar.library.pdx.edu/honorstheses

Part of the Creative Writing Commons, and the Women's Studies Commons Let us know how access to this document benefits you.

\section{Recommended Citation}

Sottura, Michela, "Reclaiming the "I": Memoir Writing as Feminist Activism" (2021). University Honors Theses. Paper 1077.

https://doi.org/10.15760/honors.1104

This Thesis is brought to you for free and open access. It has been accepted for inclusion in University Honors Theses by an authorized administrator of PDXScholar. Please contact us if we can make this document more accessible: pdxscholar@pdx.edu. 


\section{Reclaiming the "I" \\ Memoir Writing as Feminist Activism}

by

\section{Michela Sottura}

An undergraduate honors thesis submitted in partial fulfillment of the requirements for the degree of

Bachelor of Arts

in

University Honors

and

English

Thesis Adviser

Sally McWilliams

Portland State University 
Sottura 1

\section{Opening}


I came to this memoir writing knowing it would take courage. When I set out to write about my body and what happened to me, I knew I was going to have to sit with parts of myself I had long silenced, overlooked, maybe even abandoned. When I first took a class on women's memoir writing, I was struck by the power of the stories we read. I felt like a door had been opened for me as I witnessed the importance of sharing one's personal lived history. Reading the words of women with different identities and experiences than mine taught me how memoir can inspire, challenge, educate, rewrite, heal, and enact feminist change. The feminist effort of memoir lies in the radical acknowledgment of our truths, truths that challenge and complicate the one-dimensional and linear narratives that systems of oppression have build around our bodies and our identities. In my case, embracing a journey of healing and acceptance of my past and my body, motivated me to write about my own experience as a woman. More specifically, I was interested in reconciling with my body after a sexual assault and an eating disorder created an internal schism that alienated me from my embodied self. Through this process of life-writing I have had the chance to analyze the taxing experience of regulating and monitoring my body after I felt it was taken from me. I have explored and uncovered the unconscious and conscious practices crafted for my disempowerment as a woman. The process of reconciliation with myself has allowed me to be kinder by being critical of sexist, fat-shaming, and slut-shaming messages and practices I believed and engaged in for so long in the battle with my own body.

I decided to embark on this journey with a feminist collaborative spirit, engaging with another female voice to guide my own writing about my embodied experience. My obsession with the body, my body, a woman's body, has led me to read Roxane Gay's Hunger three times in the span of two years, at a time when I felt myself disassociating from my physical body. I would look at my embodied self with a clinical and critical eye, subscribing to white 
heteropatriarchal standards of what is beautiful, what is worthy. In her own memoir Hunger, Gay says "I (want to) believe my worth as a human being does not reside in my size or appearance" (17). I also struggled, and currently struggle, between wanting to believe and actually believing: I know that being a woman is more than appearance, but I also know, and have experienced, that a woman's appearance is her social currency. Specifically, whiteness, thinness, able-bodiedness are all privileges that define how the world engages with women, and how consequently women experience the world. Systems that construct and enforce racialized and gendered standards of beauty shape a woman's perception of her body. I know all of these things to be factual, and yet, just like Gay says, "what I know and what I feel are two very different things" (18). Applying this awareness to my own perception of self is no easy feat. I am constantly being told what size, what textures, what consistency my body should be. Although I know these enforced notions of womanhood only sustain a capitalist, patriarchal, racist, transphobic, and ableist system of subjugation, I have internalized these messages and have constantly monitored whether my body (and self) fits these expectations.

Adding to this context, my relationship with my body, much like Gay's relationship with hers, has been marked by something that happened in my adolescence. Like Gay, there's a before and an after in the story of my body and my relationship with it and with my female subjctivity. There's the before I was sexually assaulted at fifteen years old by a group of boys at a party: "the before" I knew what disembodiment felt like, the before I had lost a sense of control over what is done to me and what I do to myself, the before I was so desperate to re-own my body that I began denying it food, affection, sunlight, and respect.

Writing about the past, about what's happened to me, means writing from a place that looks back and examines my own memories. Writing about trauma is especially challenging as 
the events are often blurred, yet the emotions are so vivid and tangible in my body. Writing for this memoir project means mediating between the factual and the emotional, letting both shape the story--my story. I believe allowing both realities to coexist is itself a feminist act, one that recognizes the multi-faceted nuances of our reality, rejecting the white, heteropatriarchal narrative imposed upon women and our embodied experiences. The coexistence of multiple truths to one story emerges from Gay's memoir writing as well. Although our experiences in this world are very different, and our identities different, the moments where the nuanced stories of our bodies converged I felt understood. This memoir project homes in on a couple of stories of my body placed in conversation with and guided by Hunger, not trying to universalize mine and Gay's experiences, but rather believing that sharing the tale of the embodied self is an empowering feminsit act with a lasting impact. Sharing my personal experience is a feminist way of narrating the self, joining the voices of those who have shared their stories before me, and hopefully creating a site for healing for others as well. Writing about some of the most vulnerable parts of myself in this feminist collaborative spirit is important for my own healing, that of others who will see their story echoed in mine, and for disrupting systemic narratives that have been imposed on my body. 


\section{Writing the Body}

I write this with the knowledge that race, ability, class, sexuality, and gender identity interplay in shaping a body into what is desirable. Writing has the power to dispute and redefine the notions that subjugated bodies are deficient and undisciplined. Gay explores the disruptive and creative force of life-writing in Hunger, emphasizing how her fatness and Blackness in a racist heteropatriarchal world encouraged her self-conscious body-monitoring, shame, and guilt. Following a sexual assault, Gay finds comfort in food, in shaping her body as the opposite of what is desirable in order to protect herself. She describes how that very act of rebellion against the thin standard allowed her to "disappear" (13). In her eating and expanding of her own embodied self, Gay explains how she is consciously engaging in a disappearing act. A Black woman's fat body, as constructed by a white patriarchal fatphobic society, is an unworthy and deficient body. Gay has this self awareness as she realizes that "weight loss, thinness really, [is] social currency" (66). Her fat body is a problem that needs to be resolved in the context of this society, and although she intellectually recognizes that her body is not the problem, she is forced to face the reality she is living in as shaped by the dominant culture. Gay uncovers the failures of the medical community when she describes her experiences in a medical setting as a Black obese woman, as well as her highlighting of the infrastructural limitations of the physical world she inhabits. These barriers, alongside the shame and guilt she derives from overeating and obesity, enforce this need to regulate and discipline her body. Women whose bodies do not conform to societal standards face tangible disadvantages, that is why efforts to regulate one's body through self-deprivation are so prevalent in women.

I want to acknowledge the differences between my experience and Gay's. Although both of us are women who have lived through a sexual assault and consequently developed 
complicated relationships with food, my experience as a white thin ${ }^{1}$ woman is substantially different than Gay's experience as a Black fat woman. My whiteness and thinness do not disrupt the canons imposed by the heteropatriarchal society on what a female body should look like. These characteristics grant my embodied existence with privileges and a lack of barriers that fat bodies and the bodies of people of color aren't given. My experience of disordered eating and self-destruction fed into the norm rather than breaking away from it. Upon my writing and a deeper analysis of my experience, I've come to understand that Gay's disappearing act and mine, although visually opposite, called to a very similar visceral discomfort with being perceived through the male gaze following our assault. This understanding draws from the realization that appearance norms and weight norms are additional forms of gender oppression. The illusory notion of control over one's body encourages disordered eating behaviors as a means to reestablish the self-surveillance enforced by the heteropatriarchal society. My experience of anorexia and Gay's experience of bingeing and purging both fed into what the male gaze wanted us to believe: the one way to regain control over our bodies was to regulate our weight and our eating. Our memoirs refute this. Instead, the memoirs reveal that a true reconciliation with the embodied can self happen through a lengthy process of unlearning, healing, and self-love.

\footnotetext{
${ }^{1}$ Although throughout this project I will be using the terms "thin" and "fat," I am critical of them. Their definitions build on heteropatriarchal constructions of bodies, and I reject their connotation of positive vs. negative. I attach no judgement to these words, but I want to address the societal and emotional weight that they hold.
} 


\section{Part I}

\section{Disembodied}

or

\section{the Night my Body was Taken from Me}


"This is a memoir of my body so I need to tell you what happened to my body" (38)

Roxane Gay

After it happened I had a fever for four days. Fifteen years old. My throat was so sore I couldn't swallow, so my mother laid me down on the living room orange couch and placed a wide yellow bucket by my side so that I could spit out my saliva instead of swallowing it. She used to give me baths in that bucket as a baby. The fever gave me dreams that smelled like ammonia and a feeling of no-return. Asleep I was underwater, the dust floating around me, the ocean salt crusted inside my throat. Sometimes a whale would rest on my chest, moaning with me. At least there was no blood on my underwear, at least there was nobody looking. The cold January sun would wake me up and make my bones swell. All I could do was open my eyes, empty my mouthful in the bucket, and give into this muffled sleep. 


\section{New Year's Eve as Spit, or Echo}

I return in my dreams

holding my own that is creaturely.

Offering: here, I say, take me

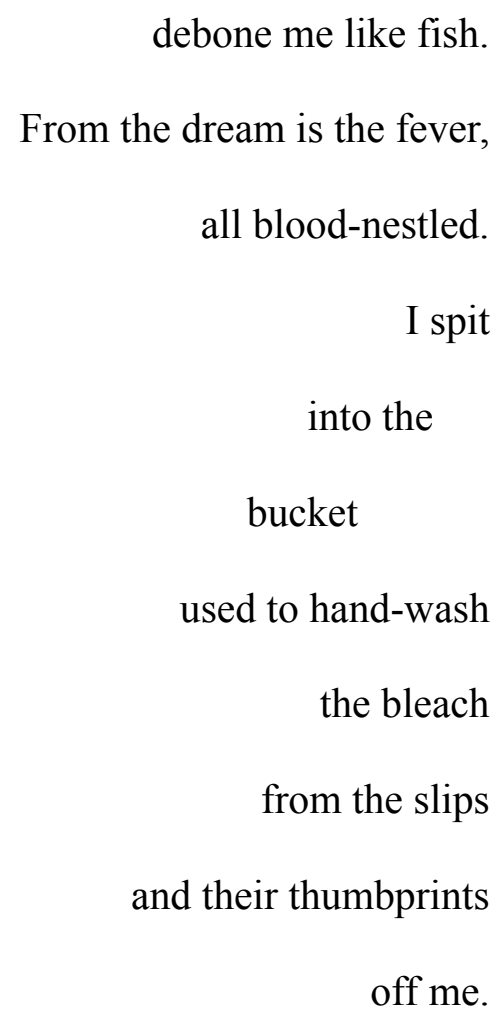

What about my body

do you wish to keep?

A sponge, blushed red ripped fibers and nerves

can't speak of

their dosing mouths

on me, hooked like fish.

The difference between truth and fact 
does not belong to me. All theirs is

the bruised animal, that's how I carry it.

It was not in dream, but there

I return to touch it,

almost tenderly.

Creaturely me, seen

through the water of memories

forcing their bodies on me.

The end of the spear

dents my hips. Would you still

take me like this 


\section{Spugne}

I didn't know I was a slut yet. What I knew was that I was sick, and so were my two best friends who came to the party with me. The fever weighed on me like thick fog. I recall that feeling in my bones. I'm thankful for that sickness now, it demanded to be tasted, survived. I had no time to inquire, to ask about what happened, to even speak about it. My body felt the foreignness of trauma and raised its temperature to fight it. As to say you don't belong here, the violence is not welcome.

While I drooled and spit into the bucket and slept in delirium, the talking had already started. On the phone screens, in between cigarettes at the park, over a sweaty beer. What happened at the party called for laughter, for sticky gossip. My friends and I would later find out, once our fevers were gone, that we had been proclaimed "sluts," troie in Italian. Dirty women, idle women, sloppy women, easy women. How do you squeeze yourself out from what others have decided you are? We laughed. When winter break ended our bodies ceased carrying the fever and school started back up. At the end of the first period a couple of girls who attended the party sat around me, eyes wide with curiosity, with judgement. How are you doing really meant why did you do what you did. I was confused, thought the fever came back. I was an active participant, I had a responsibility. I became defensive, explained that I was too drunk to remember much of the party. Explained how my friends and I could barely remember parts of the night. Explained how I did not want any of it to happen. I had not chosen to become a slut, I had forcibly been made one. The hurt of that realization is clear in my mind, sharp around the edges. What my body was, what it had become, was beyond my control.

I was particularly close with one of the girls questioning me. She told me I knew exactly what I was doing. Told me I had been irresponsible and was as much to blame as the boys who 
took me. I was missing words, missing language, missing awareness, so I believed her. The explanations I gave, the words I did have, were the words that had been instilled in me by a system that failed (and fails) to recognize girls' traumatic sexual experiences. Those boys sexually assaulted me and I had been convinced it was my fault. The language I had was the language everyone at the party and everyone who heard the stories had for me. My two close friends and I were the sluts who drank too much. Beyond sluts, the boys thought up another name for us, "sponges," spugne. Beyond the alcohol, we absorbed their bodies. 


\section{Dignity, in the name of the Lord}

The aftermath stung the most on Saturday nights, when my two close friends and I would go out to the piazza to drink and hang out with our friends. All the boys from the party would be there. Smug looks on their faces. I remember the cold, still, January. I remember wearing different heels and barely feeling my toes. I remember looking down a lot, I remember whenever there were too many people at the entrance of the bar we would have to squeeze past them and they would laugh. I remember smelling them over and over. Unable to escape. Not yet choosing to disappear. Whenever we would see them we would then run to an alley and light up a cigarette, snuggled up to each other. Not a word mentioned.

The way we coped with it was by saying that we had lost our dignity. At a loss for language, our gaping mouths could make sense of it only by framing it as something that was embarrassing, something not to be mentioned. Something like dignity, that in a deeply Catholic society meant blood on the sheets after the wedding night, meant purity, meant self-respect. We kept saying we had lost our dignity that night because it was what we had been told, never for it to be returned back to us. We left it at the party, slick on their fingers. 


\section{Fifteen}

That night I deserved to be taken care of. I deserved to be treated with care and love and respect. Instead of being touched and having their penises shoved into my mouth and their fingers inside me, I deserved to be asked if I was okay, deserved someone to be there for me and help me. I was too drunk to do that for myself and the group of boys took advantage of it. I was fifteen, I went to a New Year's Eve party with my best friends and the group of so-called "cool" boys sexually assaulted me. I wasn't the only one who was assaulted that same night, but that's not my story to tell.

At fifteen I was excited to go to this party that these highly desired boys invited us to. I wanted to kiss someone, I glowed with desire to feel wanted. I was inexperienced, insecure in my body because of ways I had been treated in the past, frequently told I was unattractive. The chance to be desired by those cool boys was thrilling. I got ready that night with an anxious heart. Wore red lipstick, black dress, skin-colored tights, high heels. Put my glasses on, sprayed perfume behind my ears, said a prayer to the Mother Mary engraving hanging above my bed, like the guilt-ridden Catholic girl I was and still am. I don't remember much, but I remember the cold, and I remember the smoke. 


\section{The Night of New Year's Eve, 2011}

The canonica is attached to the church like a boil on the skin. It protrudes out of its side, looking like something that shouldn't be there, something you're waiting on to disappear, to heal and go away. The canonica is the priest's house and where the boys held the party. The priest had taken God with him up in the mountains for a winter retreat. Everyone knows the canonica holds secrets. It swells. What do you even do to a boil on the skin? You avoid touching it, keep an eye on it. You don't meet it nails-first.

It was so cold that night, December 31 st. We walked in with our backpacks and our heels on, took a pack of cigarettes out that we would share throughout the night. We set the bags down in the dining room downstairs, the one where most of it happened, the one where a glass door leads to the garden and a wooden door that leads to that broom closet and a dilating door where I entered as a girl and left as something else, someone else. The dining table reigned in that room, I remember when the alcohol wore off and I could smell them on me, I would stare at the legs of the chairs around that table and think of how earlier one of the boys that didn't touch me (his girlfriend was there) pissed on a copy of the bible in front of everybody. I wondered if God watched. I was barely me, I was barely His child. I wondered if He watched and thought I needed that. Wondered if He saw me fall down the stairs holding on to my best friends after they managed to get me out of the bathroom where one of the boys first took a claim on my body. Wondered if He could smell the bleach they washed the whole place with, once they were done with us. Did He know that bleach is great at removing fingerprints? 


\section{January 1, 2011}

I'm fifteen, I'm delirious on the couch after some boys locked me in a boil and hurt me. The following day I have a 104 fever and a throat so sore I can't swallow my saliva. I can't eat. My body is expelling them from me. During that time I read a cheesy romance book where the main character wakes up after hitting her head and finds out she has forgotten the past five years of her life. She is now successful and beautiful and has taken revenge on those who have hurt her. It's 2021, it's been ten years for me and I'm not sure I know what revenge means. 


\section{Memories / Rendering}

Everything blurs with the drinking. What I know, what I see when I close my eyes, is the first boy taking me to the upstairs bathroom and lowering down my tights. I don't know what is happening. What I know is that I have no way out because these are the cool boys, what does resisting them look like? I ask him to stop touching me, I try to get to the glass door of the bathroom to leave because my friends are calling my name, but he pushes me against the wall, light blue tile, very 70s I remember, and puts his fingers inside me. I think one of the other boys forces the door open and there I was with my tights and panties down. I'm laying against the wall, I can barely stand. My friends, the ones I trust, are also drunk. No one to take care of us because three drunk girls at a party with the cool boys are not safe and will not be taken care of. That's what happened. After the bathroom the clock strikes midnight and we have new drinks in our hands. After midnight I'm drowning and underwater. I know they are taking me downstairs, in the big room with the table and the door to the garden and the mattresses on the floor and the door to the broom closet. Instead of giving me and my friends water, sitting us down, taking us somewhere safe to sleep, they take turns putting their fingers inside of us and shoving their penises inside our mouths. They had it all planned out, I suspect. The mattresses on the floor, the sleeping arrangements, the bleach. I smelled it for weeks after. I knew we would have stayed the night. We didn't think that sleeping over with fifteen or so other people meant that we were consenting to them playing with us. I didn't consent. 


\begin{abstract}
A First
So went my first ever sexual experience. Too drunk to stand in a bathroom with a nameless boy. Too drunk to stand in a broom closet kneeling on the ground with a penis down my throat. Too drunk to stand on three bare mattresses on the floor with two other boys taking turns at fingering me and again putting their penises in my mouth. I'm sorry for being explicit ${ }^{2}$.
\end{abstract}

\footnotetext{
${ }^{2}$ I apologize because it is not my intention to shock, or trigger the reader. I chose to be explicit in my telling of events because it is meaningful to my own healing to speak openly about details of the assault.
} 


\section{The Language Given}

The other girls at the party say:

"Those sluts."

"You know you wanted it. You knew when you went to that party what was going to

happen. You knew."

"I'm so disappointed in you."

"You deserved it, that's what you get for drinking so much."

"How embarrassing."

"How pathetic."

"Wait til they think about this tomorrow." 


\section{Opened / Ghostly}

After those boys violated me my body became an open wound. Instead of infections, it welcomed denial. The ghost haunting my body was greedy, and soon learned that in order to protect me, it had to take and take from me, until I was so detached from myself it could fully take over, and deny me of my own self. First, it denied me the truth. I became a skilled liar. I began nestling the truth in napkins, in the guise of a healthier lifestyle free of sugars and oils, wished I could hide it in toilets too but throwing up is the one thing I'm not, and was never, good at. The lying tried to keep me safe from the memories of that night by denying me sleep. My bed became an endless place of remembrance. Although the alcohol had clouded my vision and my senses, now there were flashes of hands, smells, pressure, forcing inside my body, keeping me awake. There was the re-piecing together of what our bodies remembered, and what others at the party saw. I couldn't sleep because of a looming anxiety heavy on my lungs, so I would distract myself. The ghostly voice that had entered through their breaking me open kept whispering in the dead of night, begging me to remember what had happened to me. The more I rejected it, the more desperately the ghost would howl. Look at it. Come here, take this pain and do something with it. I couldn't listen. I would stare at the light filtering through the window, the blueish light of the moon. I would keep my eyes open, alert. I always feared something would happen the moment I closed them. I had to be vigilant so that terrible things wouldn't happen to me. I had already failed once and couldn't fail twice. At night my body demanded to be listened to, telling me how scared it was of itself now that a divide had occurred. The body / the ghost. The body / me. The body / the ghost / me /. Entities at odds with each other. Enemies within me. I began dissociating from my body, finding ways to simultaneously distract and feed the ghost. I had to prove that what had happened to me happened to someone else, to a body that wasn't mine but 
that I had borrowed for that night and now had to discard. This undisciplined flesh was mine to control and shape, and what better way to do that than shrinking it, making it so small it would disappear and be harder to touch, to find, to violate. And to live in. 
You've lost the lines of your body / where once was milky moonlight pooling / now is slick blood. / How to remove a red stain from red underwear on a red morning? / Twenty eight days have not passed / you know only bitten boy nails can color so carelessly. / There is something about sacredness / or secrecy. / The limits of my skin so malleable / so welcoming? / How to close a perennial opening / when consciousness fickles / when voices are weakened?/ When the lights are turned on before dawn / and the music is stopped? / You gather the empty cups / the clear bottles / lock the door. / Let the heat wash over you / kneel in the cleansing mist. / Say this is my body / but recoil at your own touch. / Say you've grown too much / there's too much of your flesh for those fingertips. / You hear the fracture / the breaking of hard tissue / a crack in between / the you at hands' reach / and your mind writing this. / Give your body to me / says what you'll know as a sickness / give me the cherries / their stems and their leaves / give me the roots / the blossoms / the spears./ I will prune and trim / I will help disappear. 


\section{Part II}

\section{The Self Objectified}

or

the Ways Hunger Consumed Me 
"I want to disappear until I gain control of my body" (13) "I found ways to hide in plain sight, to keep feeding a hunger that could never be satisfied -- the hunger to stop hurting" (61)

Roxane Gay

When I think about blame I think of myself. I think of the active role I took to make myself smaller, to shrink myself, to starve myself. I think of the drinking, of how I had a choice to go to a different party, of how I and only I was the one deciding what goes into my body. Except it's more complicated than that. Except I know (and I'm working to feel) that it was not my fault, unlike what a misogynist world would want me to believe. 


\section{Body as "It"}

There is little choice in being anorexic, despite the many narratives that suggest so. I believed those narratives too, so much that I thought I was choosing to diet, to do something beneficial for my body. That's what I was taught that women are supposed to desire in a heteropatriarchal world. A thin body, a malleable body, a disciplined body. I thought by losing weight bad things wouldn't happen to my body anymore. I would be respectable, I would be in charge, I would have a choice about what happened to my body and how my body would be perceived. I needed to prove to myself that this body that didn't feel mine was still mine. So I began restricting my food intake, feeding into the belief that a thin body couldn't be hurt the way the body the night of the assault had been. I began exercising. I began lying. I began drifting away from the physical version of myself that had been violated, treating my body like an object that had to be fixed, that wasn't really mine, but was for other's to consume, for hunger to consume. I looked at my body with a clinical eye. It was made up of numbers and skin and fat and muscles that could be controlled with mathematical formulas. It had been ripped open, and now my job was to fix it, stop it from hurting, so that I could either find a way to live with it again after it was taken from me, or completely give it away to the pain, to the hunger. 


\section{Ghost / Fear}

When I decided the course of action for this body that didn't feel mine, I didn't realize I was choosing harm. I had been told there was no better way to love your body again than by losing weight. This messaging almost killed me. This messaging enabled me to develop unhealthy and unsustainable eating habits. It's common to think that discipline is the hallmark of an anorexic body, but anyone who's engaged in disordered eating knows there is a point where discipline isn't discipline at all. It's a lack of choice, it's a terror that leaves no room for any option other than restrict, lose weight, relish in getting smaller, and fear, fight anything that gets in the way of it. Discipline is a conscious decision, it's a purposeful decision that is renewed each day. My anorexia left room for no conscious decision.

I don't quite have the words or the knowledge to describe how my approach to reshaping my body went from dieting to eating disorder. What I know is: there was a point where I had no other choice but to listen to the irate voice of anorexia that would whisper, then yell, at any given moment about how many calories I had eaten that day, how terrible I was for having eaten more than I had promised myself I would, how miserable I was going to be for indulging in an extra almond or a piece of candy my grandmother slipped in my pockets. The anorexia became a manifestation of the ghost, a manifestation of the trauma I was carrying. I went from wanting to lose a little weight to not being able to stop losing weight. I wasn't up to me anymore, it was up to the disorder and the deep psychological fear it had instilled in me. All that was ghostly had taken over. 


\begin{abstract}
A First, Again
It's hard to point at a specific moment when the loss of control happened and the crack in my body welcomed the denial of the eating disorder. All I remember was my mother asking me to have a bite of the tiramisu we had made together, explaining how that one bite was not going to make me gain all the weight I had lost in those months after the assault, and all I could say was "Non posso, mamma." "I can’t, mom." When she would ask why, begged me to just try, it was not discipline telling me I couldn't, it was something stronger than my own will.
\end{abstract}




\section{Adjusting}

When my disorder started, my mother had no idea what had happened to me that night at the party. She still doesn't. When I began demanding my meals to be adapted to my fears, she didn't mind adjusting her cooking for me. As a woman, she had also been taught that weight-loss was to be admired. No salt, no oil, no sugar, no cheese. Smaller portions, eaten slowly, so that I could still pretend I was eating enough. Every ingredient weighed and measured, so that I could then look up the calories and continue the math in my mind. It went a little bit like this. 


\section{Mele Cotte}

Fifteen, forty-nine, ninety-five. I walk into the kitchen and the heat sinks into my bones. I'm always cold lately, even though I've been growing a thicker layer of hair on my back, my arms, my stomach. I don't mind it, it's January and I only show my skin in the dark. Fifteen, forty-nine, ninety-five. My mother is at the stove, stirring a tall pot of polenta, while mushrooms are sizzling with garlic, parsley and olive oil. Slim cuts of chicken thighs are browning in sage and rosemary. Cut up strawberries rest in the fridge, soaking in lemon and sugar. They will be topped with whipped cream and melted chocolate. Fifteen, forty-nine, ninety-five. My mouth is watering, but I swallow it all down. I sit at my spot at the dining table, barely looking at my dad or my brother, and reach for the water.

Half a clementine, seven almonds, a plain granola bar. That's been my breakfast and mid-morning snack. Half a clementine is fifteen calories, seven almonds are forty-nine, a plain granola bar, my treat for the day, is ninety-five. I hate math, but this kind of counting is exhilarating. I've become skilled at estimating, finding myself juggling numbers as I brush my teeth, tie my shoes, take notes in class, talk to my best friend, look in the mirror, all the mirrors, searching for a body I can never see. Fifteen, forty-nine, ninety-five. It's my brother's birthday, he's turning twenty. My mother is making his favorite meal for lunch, knowing it used to be one of my favorite meals too. She looks at me as I'm sipping my water. I can't look back, but I feel her gaze on my shaky hands.

"What are you making for me," I finally ask.

I expect her to try and convince me to join the feast, maybe just for a bite of the mushrooms and some of the strawberries, without the soft whipped cream and the warm gooey chocolate. There is oil and salt in the mushrooms, too much sugar in the strawberries. She knows 
I can't and won't eat any of it. I expect her to fight with me, raise her voice, sending my dad in a spiral where he'll tell us to go to hell, push the table away, storm into his office throwing things around as he goes. Matteo will then join my mother's yelling, saying something along the lines of "look at what you've done."

"Mele cotte." Ma says. She grabs a bowl filled to the brim with stewed apples. "This is what you wanted, right?"

She places the plate right in front of me, without meeting my eyes. The apples are warm, steam rising to fog up my glasses. My dad and my brother watch me, waiting. Fifteen, forty-nine, ninety-five, one hundred and ten.

I give my final answer. "Yes, thank you."

For the next hour I will make this bowl of apples my one and only focus. Sometimes I'm amazed at how slowly I can work through the meal. I look at my hand, wondering if my mother has noticed that the knuckles have gotten more prominent, the skin has sunk into them, and my wrist can fit the bracelets I wore as an eight-year-old for my first communion. I grab the spoon and look away from the plate of polenta, creamy garlicky mushrooms, tender golden chicken, all swimming in herbed warm olive oil. I don't listen to my family's mouthfuls, their chewing and swallowing each bite with all of their hearts in it.

Or maybe I listen too closely and I think, just for one second, that maybe I could just have a little taste of the mushrooms, just to see if it's like I remember. I stare into my bowl of stewed apples. One hundred and ten calories, added to the breakfast and snacks I had this morning, comes to over two hundred calories. It's only midday and I can't risk it. I have to save the calories, just in case tonight I overeat to the point where I'll gain weight and take up more 
space and lose control of my body and then I'll be so easy to grab and hurt. There'll be more of me to hurt.

The stewed apples meet my mouth slowly. Their tangy sweetness is soft on my tongue. I chew and chew and chew, rolling the pulpy mush around. Once there's no more to chew, I swallow. Take a sip of water. Set the spoon down. Talk a little about school. My parents enjoy it when I distract them from my ridiculous ritual. That's what eating has become. A ritual of cutting back, counting up, categorizing food into the bad and the good, the dangerous and the harmless. If I stopped the ritual maybe I would stop growing hair on my body, I wouldn't shake so much, I would get my period back. But this denial tells me I'm perfect. I don't make a mess in the bathroom each month, wiping the blood off my hands and off the toilet seat. I fit into lots of clothes I never imagined wearing. My friends and my relatives compliment my shrinking, nodding and clapping at how small I'm becoming. I'm meeting the expectations about female embodiment, I am occupying less and less space. I am accommodating to male gaze, to a patriarchal, fat-phobic world. Others confirming that my body is changing and pleasing them, lets me know that my work to disassociate from my trauma, my body split open, is somehow working. Although rather than enabling healing, it's fostering self-harm. The denial makes my heart beat too fast and a bowl of stewed apples calls itself a celebratory meal and my mother will eventually cry in the living room because I need to eat . Fifteen, forty-nine, ninety-five, one hundred and ten. My body is disappearing. You can’t touch it. 


\section{Denial Denial Denial}

Deep into the disorder of eating I found comfort in the restricting, counting, tracking, measuring, sometimes spitting out food in napkins. It was exhilarating to see the bones peek through, the shoulder blades cut through my clothing, my knees so sharp they would bruise each other when they touched. There were not many other ways for me to find comfort in the harming--fixing--of my body when I didn't feel at home in it, when it had been violated. I found power in this thinness. The social currency of a slim body that doesn't take up space, that fits into narrow spaces and narrow clothes and narrow minds.

Deep into the disorder I cried at the dinner table countless times. Scared of a plate of pasta that instead of having just warm unseasoned tomato sauce had a drizzle of olive oil and some parmigiano on it. Scared of cured meats and their sodium. Scared to even touch a buttery pastry. I sobbed, I yelled, I feared food to the point of cancelling plans with my friends because I would have to pretend I was eating the birthday cake or the pizza they ordered, to the point of lying and lying to all those I loved and all those who loved me. Scared to be seen, to be fed, to be loved, to be touched. Anchored only in the denial. 


\section{Unfitting}

After seven years

the water calmly browns

and I can sweep the moths' wings

At my feet. I recall the hunger

as the before morning feeling.

I gather it behind my teeth claiming it still

Belongs to me. That possibility,

the empty glass between my legs

Lost in the hush of my evening.

I skin, I sink, I still

Bruising knee bones in sleep.

Watch the light press on

my window, I pray

To never need salt, as she leaks

Through me.

My mother begs

For blood, for bleeding marks

The calendar and records the news

To show me bodies unfit for pregnancy.

She begs, what else to do? 
only in her body ever

Was I free? I keep, I eat, I count

The ways my jawbone squeaks. Sure

Of her crying my guilt.

It was all desire, you see

the ricochet,

The foam, the orchids turned moths

The bleach. 


\begin{abstract}
Another Loss
Two of my mother's biggest fears, still to this day, are for me to get too drunk and have something terrible happen to me, and for me to be sick. Oh, the irony. Now that I live miles away in a different country, the ways she makes sure her biggest fears don't come true is by asking for a text after every night out and tracking my periods, anxiously waiting every month for the news of my bleeding. When I began measuring my eating to the point of obsession, to the point of disorder, my period stopped. My body, this body I felt alienated from after my assault, couldn't sustain my menstrual cycle. It's really no wonder when considering the extreme weight loss, paired with at least an hour a day each day on the old stationary bike in my dad's office, or an hour and a half a day each day on the treadmill my mother bought my cancer-ridden grandmother for her to do some physical exercise, paired with the angry voice of anorexia in my head occupying all my waking moments. It's no wonder that my undernourished body had to conserve fuel to keep me alive, rather than using the little energy I would grant it (or my disorder would grant me) for my reproductive system. The absence of my period meant my body was not functioning properly. Meant I was, in some way, sick.
\end{abstract}




\section{Woman to Woman / Girl to Mother}

The loss of my period, alongside my increasingly frequent tantrums around food, the weekly decline of the number on the scale, and the visible effects of starvation on my skin (sharp peeking bones, lanugo, paleness, bruising) caused a shift in my mother. Again, I don't recall the exact day it happened, all I know was I kept counting the shrimp on my plate, tail by tail, going over the math in my head. With two pieces of shrimp left in the pan, she kept begging me to eat them. "It's two more, please." I kept refusing, and like it often happened between us, the disagreement turned into a yelling match, until I started sobbing. "I can’t." I had told her before. "I can't." She began crying too. For the first time I was witnessing my mother crying over me, over my withering, my disappearing body. She was desperate for my survival. Still to this day, she tracks my period to track my survival. She sees the menses as a sign of my health, as proof that I am eating. That I can, in fact, eat a little more shrimp.

At first, in the aftermath of her crying, the ghostly voice of anorexia suggested it was envy. Her, and everyone around me wanted me to eat, to bleed, and to gain weight, like it was some horrible curse. After all, I kept being reminded that as a woman I was supposed to desire the thinning, over and over again. No thin was thin enough. I kept being reminded that since those boys had split my body open, I needed it to disappear, to stop being a body that could be hurt, a body that ate and bled. 


\section{Consumed}

When I bled that night of the assault the bleeding was translucent. It reminded me of when I bled for the first time at nine years old. When I was playing a computer game and wearing a long green skirt after mass. I felt ashamed the morning after the assault, when I found blood in my underwear, just like I felt ashamed that afternoon of my first period when I found smears on my butterfly-print panties. So much shame came with the bleeding. I felt the need to hide it because I was too scared of it, too worried of what might have come of it.

Eating again, admitting that I was letting the hunger consume me, my mother's crying, bleeding again, all meant having to return to the part of myself that had been silenced by the ghost of trauma. It meant acknowledging it was there, and the hurt it carried didn't have to be in charge of me. It meant reconciling with the body that had been taken away from me, making peace with it rather than punishing it to feel somewhat in control. It meant learning to love it. To love me. 


\section{Recovery}

My body had shown me it wanted me to eat through the loss of my period. My mother had shown me she wanted me to eat through her crying, her begging. My trips to the doctors had become more frequent, and they all ended with a simple imperative: I needed to eat.

Again, I can't think of the specific moment I began actively engaging in the recovery, the healing. I do remember that I felt that I was failing as an anorexic. I kept thinking that choosing to eat meant I had not been and was not a good anorexic, I could have been better. I could have kept giving in to the ghost of hunger for longer. My rebellion against my body could have lasted to the point of hospitalization. Who would wish for feeding tubes, for hair loss, for heart failure? Who would think weight gain is scarier than death? When I began asking myself those questions, when I looked online for other women who had experienced or were experiencing anorexia, I knew I was shifting. I knew I was returning to my body.

Silencing the voice of anorexia is an ongoing process, but when I first started it, I was engaging in the radical act of asserting my agency over my body for the first time since the assault. That traumatic experience and the takeover that anorexia had enacted on my psyche had denied me any sense of true control over myself for years. Choosing to embark on the journey of unlearning meant letting go of the guilt--the guilt of eating and gaining weight, the guilt of refusing food when you have plenty, the guilt of agency, the guilt of lack of agency. My body, the site of all that hurt, needed to be reclaimed by me. 


\section{Unlearning}

When I forced myself to take that first bite of pizza with melting gorgonzola and olives on a casual Monday afternoon, it didn't feel like a monumental act of self-love. When I ate a piece of the chocolate egg with hazelnuts on Easter morning, it didn't feel brave, or revolutionary. When a boy touched me again, after I said I wanted him to, it didn't feel healing. But it all felt necessary. Everyone says recovering isn't linear, and only now, after ten years from my assault and my eating disorder I fully understand it. I write this looking back and recognizing that the event of my assault doesn't define me, nor does the ongoing struggle with eating and anorexia. I write this and I know I am still unlearning. That each day I choose to eat, to care for my body, to see my body as part of me, not all of me, not detached from me, I am engaging in this unlearning. This process is a necessary component to the healing, and it's what has allowed me to write about these experiences of my body. A body deserving of love, compassion, good food, gentleness, consent, and hunger for life. 


\section{Poem To The I Who Chose to Eat Again}

To you, I'd love to show the breakfast a man you loved makes you. The skillet de huevos, papas, salsa verde, deseo. To you, I'd love to show the aftermath of a transatlantic flight. The steaming pan of orecchiette, sugo, casa. To you, I'd love to show your open mouth. The tenderness of the nerve endings, the warmth of survival.

To you, I'd love to show your body as shelter. I mean as comfort. I mean as shield. I mean as home. It comes, it becomes. To you, yours. Wounds welcomed infection, welcomed denial. Yes, and: transformation, a peaceful thickness. I'd love to show you, to you, the red pools of the tide, their softness and their clotted flowers.

To you, I'd love to show the lips of indulgence, the buds of hunger open rich and wide. I'd love to show the stove of your first apartment, the boiling saltwater, the wandering steam rising from dinner into your grateful nostrils. To you, a prayer you can answer. The world edible, outrageously offering. To you, all dedicated from me to you, me, I. 
Sottura 41

\section{Reconciliation}


The opening section of this project explored the feminist power of memoirwriting. As I set out to write the pieces included in this thesis, I felt comforted knowing that the act of telling my story had the inherent potential to cause some sort of societal change. The writing of sexual trauma and its aftermath, voicing it and making it public was a brave act. It was a powerful feminist act that placed my voice and my experience as a creative site of knowledge-production. As I was writing these pieces though, I did not always feel like I was making some empowering and radical work. I felt challenged, sometimes defeated, other times so stuck I was unsure my story was even worth telling. I don't mean this in a self-commiserating way, I rather want to highlight the contradictions and constant internal battles that one is bound to face when challenging oppressive heteropatriarchal notions around one's embodied female self. The feminist collaborative spirit of this project allowed me to push past my own internalized blocks. Only through the inspiring work of women before me who have written about their own trauma was I able to engage in this journey. The works of Roxane Gay, Carmen Maria Machado, Kai Cheng Thom, to name a few, enabled and comforted me, allowing me to experience the power of the personal. Returning to Roxane Gay's Hunger, especially her words about the desire to belive that her worth does not reside in her body or her appearance, and her assertion that knowing and feeling are two vey different things, kept ringing true. Gay's feminist guidance, her own feminist labor directly impacted me and helped open the doors to my own healing. When I heard my story echoed in hers I felt validated. I felt empowered to challenge all the years of slut-shaming and body-policing I experienced and internalized. Her honesty about her past, about the emotional toll that writing about her most intimate memories took, about the procrastination, the shame, but also about the necessity of telling her story enabled me to embark on this journey. Gay's memoir 
radically impacted me, and millions of her readers. Her perspective as a Black, fat, woman is more than necessary, and I am grateful for it, for her bravery.

I chose to write about what happened to me because it felt necessary, but also because it felt like the perfect culmination of the work I've done throughout the past four years in college. I moved here from Italy to fulfill a dream, and experienced incredible growth, both intellectually and emotionally. During my college experience here I educated myself about sexual assault through a feminist lens. I expanded my feminist knowledge through Women, Gender, and Sexuality courses. I found language for my experiences that validated them, rather than questioning them and shaming me. I learned to look at the world through different lenses, learning from the intersectional experiences of systemically silenced groups. Being here immersed in this knowledge-producing environment meant being away from the people who assaulted me and those who witnessed (and weighed in) on the aftermath of the assault. I allowed myself to tend to the parts of me that were hurt and neglected. I have worked to reconcile myself and my body, welcome healing, and move towards a loving relationship with my own embodied self. 
Sottura 44 


\section{Writing the Body, Again}

Writing about my body and what's happened to it has been an emotionally-draining but ultimately empowering act. As I mentioned before, it has been a fundamental part of my healing. The pieces I share reveal some of my most vulnerable and unspoken experiences. I have been on this journey of healing for years, and now, after ten years from my assault and the height of my anorexia, I am able to write about them. Recovery is a long and imperfect process that needs constant effort. The tension that emerges in the pieces is indicative of this process. Contradicting truths coexist, as my own perceptions of my body and what's happened to it are challenged by my desire to heal and the external messages that foster the shame and the self-loathing. Gay in her own conclusion writes that she is "working toward abandoning the damaging cultural messages that tell me my worth is strictly tied up in my body" and is "trying to undo all the hateful things I tell myself" (301). It takes constant unlearning and undoing while simultaneously acknowledging that every step towards self-love that rejects notions enforced by a capitalist, patriarchal, racist, transphobic, and ableist system is necessary, knowledge-producing, and worth it. 


\section{Body as the Io, and the Io Beyond Body}

The I embodied is the only one I

can touch, mark. I am part of that I,

I inhabit its ridges, its stark presence

on the page. I translates as

Io, yo, all me. I claim I

in the marshes of existence and

forgive the timesI slipped from me

my body from me I from my body.

I refuse to be all body, but love

to be body at all.

I thank my I-shaped limbs,

the organs, the liver also I

the ribs also I, the eyes also I.

I revere the hillsides of my

intestines and the storms

in my ears. All I, all me. 


\section{Acknowledgements and Bibliography}

As part of this feminist collaborative work, I want to hold space in this project for the incredible women who have done the work before me. I want to thank them for the infinite doors they have opened for others, especially for other women writers. I want to thank the feminist, BIPOC, queer, trans, disabled women who continuously inspire me and educate me.This bibliography includes authors, artists, and scholars who have shaped my writing of this thesis. I want to take this space to give a special thank you to my advisor, Dr. Sally McWilliams, who was by my side through every step of the way. This work would not be here without her knowledge, feedback, constant encouragement, intellectual and emotional support, and brilliant perspective. Thank you Sally, I will forever be grateful for this collaboration.

Bechdel, Alison. Fun Home: A Family Tragicomic. Houghton Mifflin, 2015.

Chrisler, Joan C., and Ingrid Johnston-Robledo. Woman's Embodied Self: Feminist Perspectives on Identity and Image. American Psychological Association, 2018.

Cvetkovich, Ann. An Archive of Feelings: Trauma, Sexuality, and Lesbian Public Cultures. Durham NC: Duke UP, 2003.

Fallon, Patricia, et al. Feminist Perspectives on Eating Disorders. Guilford Press, 1996.

Fredrickson, Barbara L., and Tomi-Ann Roberts. “Objectification Theory: Toward Understanding Women's Lived Experiences and Mental Health Risks.” Psychology of 
Women Quarterly, vol. 21, no. 2, 1997, pp. 173-206., doi:10.1111/j.1471-6402.1997.tb00108.x.

Gay, Roxane. Hunger: A Memoir of (my) Body. New York, NY: Harper, an imprint of Harper Collins Publishers, 2017.

Garland-Thomson, Rosemarie. "Integrating Disability, Transforming Feminist Theory." Gendering Disability. Eds. Bonnie Smith and Beth Hutchison. New Brunswick: Rutgers UP, 2004. 73-103. Print. .

Gilmore, Leigh. "MeToo and the Memoir Boom: The Year in the US." Project Muse, Bibliography (Honolulu), 2019, Vol.42 (1), p. 162-167.

Heywood, Leslie, and Morag Macsween. “Anorexic Bodies: A Feminist and Sociological Perspective on Anorexia Nervosa." Contemporary Sociology, vol. 24, no. 1, 1995, p. 43., doi:10.2307/2075083.

Kafer, Alison. Feminist, Queer, Crip. Bloomington: Indiana UP, 2013. Print.

Lanser, Susan S. "Toward a Feminist Poetics of Narrative Voice." Fictions of Authority: Women Writers and Narrative Voice. Pages 3-24.

Lorde, Audre. Zami: A New Spelling of My Name. Freedom CA: The Crossing Press, 1982.

Machado, Carmen Maria. In the Dream House. Minneapolis, MN: Graywolf Press, 2019.. 
Morrison, Toni. "The Site of Memory." Inventing the Truth: the Art and Craft of Memoir. Ed. William Zinsser. 2nd edition. Boston: Houghton Mifflin Co, 1995. P. 83-102.

Nguyen, Bich Minh. Stealing Buddha's Dinner: a Memoir. Penguin Books, 2008.

Smith, Sidonie, and Julie Watson. Reading Autobiography: A Guide for Interpreting Life Narratives. Second Edition. Minneapolis: University of Minnesota, 2010.

Thom, Kai Cheng. Fierce Femmes and Notorious Liars: a Dangerous Trans Girl's Confabulous Memoir. Zubaan, 2019.

Van Amsterdam, Noortje. "Big Fat Inequalities, Thin Privilege: An Intersectional Perspective on 'Body Size.”' European Journal of Women's Studies, vol. 20, no. 2, 2013, pp. 155-169., doi:10.1177/1350506812456461. 